MIP

30,3

284

Received 7 April 2011

Revised 14 October 2011

3 November 2011

Accepted 8 November 2011

\section{The impact of internal and external market orientation on performance in local public organisations}

\author{
Ana Paula Rodrigues
}

Department of Economics, Sociology and Management, University of Trás-os-Montes and Alto Douro, Vila Real, Portugal

José Carlos Pinho

School of Economics and Management, University of Minho, Braga, Portugal

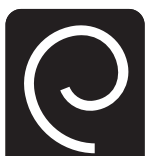

Emerald

Marketing Intelligence \& Planning Vol. 30 No. 3, 2012

pp. 284-306

(C) Emerald Group Publishing Limited 0263-4503

DOI $10.1108 / 02634501211226276$

\begin{abstract}
Purpose - This study aims to build on and extend the literature of market orientation by examining the impact of sub-dimensions of both internal and external market orientation on financial and non-financial performance in the local public sector context.

Design/methodology/approach - In line with previous studies on market orientation, a quantitative research design was adopted. The data collection was performed through a mail survey of a sample of local Portuguese public organisations (municipality executive board members). Structural equation modelling was used as a means to analyse the hypothesised relationships.

Findings - Six out of 12 hypotheses are supported. Concerning the sub-components of external market orientation, the study finds that the dissemination and responsiveness of external information impacts strongly on non-financial performance. In turn, external information generation and responsiveness impacts positively on financial performance. With respect to internal market orientation, results revealed a lower impact of different sub-dimensions on performance. Specifically, the only dimension that impacts positively on organisational performance (financial and non-financial) is internal information generation. This reinforces the view that there is a need to strengthen internal information dissemination and responsiveness to enhance organisational performance.

Originality/value - This paper offers original and unique findings and to the best of the authors' knowledge this research is one of the few studies addressing the role of internal and external sub-dimensions of market orientation on performance in the local public sector. The findings of this study add weight to the recent emphasis on disaggregate approaches to (internal and external) market orientation-performance link.
\end{abstract}

Keywords Market orientation, Internal marketing, Organizational performance, Local public sector

Paper type Research paper

The authors are grateful to the Editor (Professor Gillian Wright) and the two anonymous reviewers for their constructive comments on an earlier version of the article. The authors also inform that this research is financed by national funds through FCT - Foundation for Science and Technology by the Project PEst-OE/EGE/UI4021/2011 and by the project PEst-OE/SADG/UI4011/2011. 


\section{Introduction}

Worldwide, public sector organisations are facing a vast number of unpredictable challenges. A process of deep transformation has been encouraged by the introduction of market-style supply associated with the growth of contract-based services, and concepts such as efficiency, effectiveness, accountability, transparency, value for money and market orientation, which rapidly transposed the domain of the private sector and expanded it to public and non-profit sectors (Harris, 2003; Macedo and Pinho, 2006). Basically, this trend follows the New Public Management (NPM), which in its simplest form views the government from the standpoint of markets and customers. That is, public organisations should adopt practices, ranging from "scientific management" to "total quality management" that have been found relevant in the private sector (Denhardt and Denhardt, 2000).

Building on this point, we concur with several authors who argued that "key elements of the practice of the NPM included an attention to the lessons from private sector management, a focus upon entrepreneurial leadership... and the growth of the use of markets and competition as a key allocative mechanism for delivering public services" (Osborne, 2010, p. 2). Besides, it has been recognised that the growth of a firm oriented culture led public and non-profit organisations alike to become preoccupied with meeting demands of "sovereign consumers" (Keat and Abercrombie, 1991). The effects of worldwide changes and challenges arising from the application of the fundamental tenets of NPM were also addressed by Hood (1995).

Portuguese public administration is not an exception to this ongoing global trend. In fact, several initiatives have been taken to provide better public service, to increase the level of education and training of public servants and to improve the use of the available resources, raising efficiency and efficacy (Araújo, 2001). As acknowledged by several authors, Portuguese public administration is being renovated in order to bring about a new organisational model that is less bureaucratic, more efficient and more needs-based with respect to citizens and other stakeholders (Pinho et al., 2007; Rodrigues and Pinho, 2010). The movement to customer/citizen-centred government provides the rationale to emphasise the importance of strategic marketing and, as a result of that, the opportunity to integrate the concept of internal and external market orientations within the context of public sector agencies. Relevant literature acknowledges that, as in the case of business firms, there are numerous advantages associated with the adoption of a market orientation in the context of public and non-profit organisations. More specifically, it simplifies not only the design of the most appropriate services to the target public but also provides superior customer value leading to major performance (Andreasen and Kotler, 2003; Pinho et al., 2007).

The market orientation (MO) concept, which has gained an outstanding position in the marketing literature, is still a research priority (Cano et al., 2004), particularly in local public organisations. The main research stream on market orientation-performance relationship emphasise the exchanges that occur between the organisation and its external markets. Some scholars, however, have paid increasing attention to the need to integrate an internal and external focus (Lings, 1999, 2004). It appears, therefore, that an internal focus on marketing (internal marketing) is important to promote the organisation internally to its employees and, at the same time, a better adaptation of the employees to organisational procedures and changes (Gummesson, 2000). It is relevant to note that, the successful public service providers
The impact of market orientation

285 
MIP

30,3

286

lies both in governing and responding to the service expectations of consumers and in training and motivating the organisation to interact positively with the consumer (Osborne, 2010).

The primary goal of this article is to examine, from an integrated perspective, the impact of each internal and external market orientation dimension on organisational performance in the public sector administration context, and as a consequence, to address some New Public Management principles (Rod and Ashill, 2010). It is assumed that a market orientation consists of a group of activities, which translate a marketing philosophy into practice through the generation, dissemination and response to market information (Kohli and Jaworski, 1990). Implementing an internal and external market orientation in public organisations requires the alignment of people, processes, and policies in a transformational manner with the ultimate objective of creating advantages for both publics: employees and customers/citizens (Rodrigues and Pinho, 2010).

Evidence from various studies also indicates that both internal and external market orientation have significant effects on different measures of organisational performance. Most existing studies focus mainly on the overall measure of market orientation (internal/external), and far less attention has been paid to the impact of each market orientation component on organisational performance (Narver and Slater, 1990; Han et al., 1998; Noble et al., 2002).

Concerning organisational performance in the public sector, it may be worth noting that the adoption of both financial and non-financial indicators is a better approach when considering the overall performance of an organisation (Venkatraman and Ramanujam, 1986). Moreover, it should be emphasised that some measures of performance are selected by governments and their representatives, so in some cases their choice reflects the priorities of powerful groups within the state (Andrews et al., 2011). The present study builds on and extends the literature of market orientation in three ways.

First, this study departs from existing literature by taking a sub-dimension approach to internal and external market orientation. Most of the literature to date has used an aggregated approach (Furrer et al., 2003); however, the study of the independent effects of market orientation dimensions (internal/external) on organisational performance has not been researched, apart from several notable exceptions (Dawes, 2000; Noble et al., 2002; Sin et al., 2005; Zhou et al., 2007; Tsiotsou, 2010).

Second, the study extends current research by examining the effects of the implementation of market-oriented behaviours in the context of local public organisations. A balance between internal and external market orientations will provide a different view and a unique opportunity for local public sector organisations to achieve their mission and improve their performance.

Third, the analysis of the impact of market orientation dimensions both internal and external to organisational performance is examined. This objective is in line with a number of scholars in the areas of strategic management and organisational marketing who have recognised the importance of achieving a balance between an internal and external focus (Lings, 1999). Examining an internal market orientation perspective contributes to a better understanding of an organisation, promotes its services internally, to employees, and at the same time contributes to a better adaptation of employees to organisational procedures and changes (Gummesson, 2000). By doing this, employees are better prepared to deal with external environmental challenges increasing chances of success of the organisation. 
In the remaining parts of this paper, the conceptual framework and research hypotheses are reviewed. The methodology is then explained and the findings are explored along with a discussion of theoretical and managerial implications. Limitations of the study and future research directions are identified.

\section{conceptual framework and research hypotheses}

The need to respond to profound changes that occur in most societies leads public managers and academics alike to pay increasing attention to the way organisations develop and maintain their focus on their customers and markets (Appiah-Adu and Ranchhod, 1998). However, focusing on the external customer no longer seems to be sufficient to achieve organisational goals and objectives. If employees lack customer-conscious attitudes and behaviours, and if internal systems and processes are not focused on customer-conscious objectives, marketing approaches directed exclusively at external customers are likely to fail.

Accordingly, a balanced perspective should be taken into account, particularly by considering the relative importance of internal and external market orientation dimensions on performance. This can be better understood through the conceptual model proposed in Figure 1.

As can be seen in Figure 1, two major relationships can be found. First, the impact of internal market orientation dimensions on both financial and non-financial organisational performance. Second, the impact of external market orientation dimensions on both financial and non-financial organisational performance.

\section{External market orientation dimensions and organisational performance}

For the past few decades, the concept of market orientation has dominated the theory and practice of marketing strategy. There is broad recognition that market orientation is the implementation of the marketing concept (Kohli and Jaworski, 1990; Narver and Slater, 1990). As a result, a market-oriented organisation is one whose activities incorporate market-related activities.

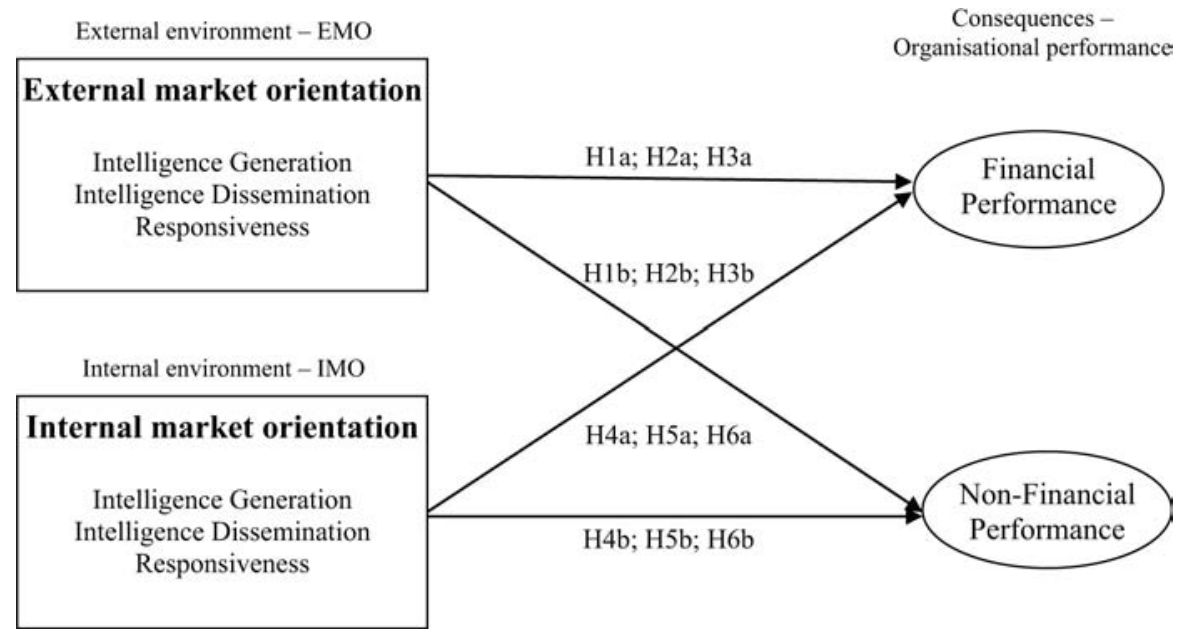

\section{The impact of market orientation}

287 
MIP

30,3

288
The systematic study of market orientation began at the beginning of the 1990s and has been conceptualised in the literature in different but related approaches. However, two conceptualisations of market orientation have gained wide support (Piercy et al., 2002). The behavioural-based view of market orientation developed by Kohli and Jaworski (1990) and the culture-based interpretation of market orientation tested by Narver and Slater (1990). In this study, the approach of Kohli and Jaworski (1990) on market orientation has been adopted.

On the basis of their behavioural conceptualisation, Kohli and Jaworski (1990) have identified three main sub-dimensions of market orientation which are:

(1) organisation-wide generation of market intelligence relevant to current and future customer needs;

(2) cross departmental dissemination of the intelligence; and

(3) organisation-wide responsiveness to it.

Different activities are associated to each market orientation dimension (Li and Calantone, 1998). For instance, the first component called market intelligence generation refers to the process of continuous monitoring and gathering of information on both the current and future needs of customers, and analysis of the exogenous factors that may influence those needs (the impact of government regulation, competition, technology and other environmental forces). The second component refers to the dissemination of market intelligence, which is the vertical and horizontal flow and sharing of information gathered at the early stages of an organisation. The last component of external market orientation is called responsiveness and includes actions involving the design and selection of products and services, the production, distribution and promotion of the product.

Over the last few years, there have been a vast number of studies examining the relationship between the degree of market orientation and organisational performance. For example, there are several studies that demonstrate the existence of a positive and significant relationship between these two concepts (see the meta-analysis conducted by Cano et al., 2004 and Kirca et al., 2005 for a review). In other words, most previous studies assume that the implementation of a marketing philosophy will almost inevitably lead to superior organisational performance (Piercy et al., 2002). This relies on the fact that a market-oriented posture creates a favourable environment to fulfil the customer's needs, thus causing a positive impact on customer satisfaction (Kara et al., 2004). Similarly, in the context of the local public sector, prior research has also demonstrated a direct causal relationship between (external) market orientation and organisational performance (Cervera, 1998; Caruana et al., 1998; Cervera et al., 2001; Rodrigues and Pinho, 2010).

Although previous research has theoretically claimed - and provided empirical support for - a positive relationship between market orientation and organisational performance, there are a number of issues that have hardly been explored by relevant literature such as the impact of the sub-dimensions of market orientation on non-financial and financial indicators of performance. The assessment of organisational performance is a recurring theme in the management and marketing literature and has been under extensive empirical investigation. In the vast majority of market orientation studies the organisational performance construct has mainly been operationalised through financial measures of performance (Jaworski and Kohli, 1996). However, this perspective has been criticised by several authors (Brignall and Ballantine, 1996). Due to this drawback and in order to provide an integrated 
perspective of organisational performance, several authors also included non-financial indicators (Panigyrakis and Theodoridis, 2009).

Taking all of the above into account it is also important to emphasise another issue in market oriented research, which is related to a sub-dimension market-oriented approach. This concern can be linked with a position taken by Narver and Slater (1990) who have called for future studies that examine "the effect of the proportions of the components within a given magnitude of market orientation" (Narver and Slater, 1990, pp. 33-34). In order to accommodate this issue, recent research has addressed a decomposed approach of the market orientation construct emphasising the relative value of its different sub-components (Han et al., 1998; Dawes, 2000; Voss and Voss, 2000; Lukas and Ferrell, 2000; Noble et al., 2002; Tsiotsou, 2010). In line with this, Carver (1989) pointed out that with this approach a greater predictive capability of individual components of the construct of market orientation can be achieved.

Even so, the need to examine a sub-dimension approach of market orientation can be theoretically justifiable (Dawes, 2000) and more empirical research is required, especially because the findings concerning the role of the three market orientation components has not been consistent in the literature (Tsiotsou, 2010). The importance and the role of the three market orientation dimensions suggested by Narver and Slater are questioned and the empirical studies to date provide mixed results about their contributions to the construct (Zhou et al., 2007). In some studies (Dawes, 2000; Noble et al., 2002) the competitor orientation component is the strongest determinant of performance; other studies (Balakrishnan, 1996) reported that both customer and competitor orientation are positively associated with performance. An indirect relationship between customer orientation and performance through its effect on innovativeness was also considered by Han et al. (1998). In the research of Sin et al. (2005), the only market orientation component that shows a significant positive effect on (market and overall) business performance is customer orientation. In the same vein, Zhou et al. (2007) report of the three market orientation dimensions only customer orientation is significantly associated with and impacts on performance. Similarly, Tsiotsou (2010) also pointed out that the customer orientation was the only sub-dimension that revealed a direct impact on organisational performance.

Additionally, by taking a sub-dimension approach, most studies on the topic have used the Narver and Slater (1990) components of market orientation, whereas the Kohli and Jaworski elements of market orientation are less studied. Moreover, it should be emphasised that most sub-dimension approaches are typically confined to for-profit organisations and produce an undesirably simplified approach to the reality since they capture only a partial or biased picture of this reality (Day and Wensley, 1988; Tsiotsou, 2010).

Against this backdrop, this study investigates the market orientation-performance relationship within a specific local public sector, taking the different sub-components of the market orientation construct proposed by Kohli and Jaworski (1990). Thus, the following hypotheses are offered:

H1. External information generation (IG) has a direct, positive and significant impact on financial performance (H1a) and on non-financial performance $(H 1 b)$.

H2. External information dissemination (ID) has a direct, positive and significant impact on financial performance ( $H 2 a)$ and on non-financial performance $(H 2 b)$.
The impact of market orientation

289 
MIP

30,3

290
H3. External responsiveness (R) has a direct, positive and significant impact on financial performance $(H 3 a)$ and on non-financial performance $(H 3 b)$.

It is widely recognised that the concept of market orientation constitutes the cornerstone of both marketing and strategic management (Greenley, 1995) and, traditionally, it reflects an external orientation of the organisation toward their markets. This study goes further by simultaneously analysing this external perspective and an internal view of the organisation. This view is particularly important since in the last few years, particularly in the for-profit sector, there has been an increasing body of literature supporting the theory that internal marketing activities are vital to external marketing strategy and successful orientation (Grönroos, 1981; Ballantyne, 2000; Rafiq and Ahmed, 2000).

\section{Internal market orientation components and organisational performance}

Internal marketing is considered a key factor not only to attain service excellence but also to ensure the success of external marketing by strongly motivating public employees (Greene et al., 1994). The concept of internal marketing originally emerged from the services marketing literature, and was proposed as a solution to the problem of delivering consistently high service quality (Rafiq and Ahmed, 2000). Since its introduction in the 1980s by Berry (1981) and Grönroos (1981), internal marketing has gained the attention of academic professionals in the area of marketing and other fields (Varey and Lewis, 1999). One important definition of internal marketing was that presented by Rafiq and Ahmed (2000, p. 454) who defined this construct as "the planned effort using marketing as an approach to overcome organisational resistance to change and to align, motivate and inter-functionally co-ordinate and integrate employees towards the effective implementation of corporate and functional strategies in order to deliver customer satisfaction through a process of creating motivated and customer oriented employees".

Internal marketing is defined as a set of employee-friendly managerial behaviours (Lings and Greenley, 2005), and its implementation has been operationalised by recent studies through the internal market orientation construct (Panigyrakis and Theodoridis, 2009). Internal market orientation is a mechanism for instilling a "people" orientation into an organisation, and a prerequisite for improving and strengthening the quality of public services among employees (Papasolomou, 2006) within public and non-public organisations.

Conceptually, this construct is similar to external market orientation (Lings, 2005). With the aim of adapting this construct to internal environment, Lings and Greenley (2001), Lings (2005) acknowledged that the same three behavioural components proposed by Kohli et al. (1993) are at the core of the internal market orientation construct (Kaur et al., 2009). Therefore, information generation is relevant to the internal market as it relates to employees' perceptions of the inputs to their jobs, the outputs (what they receive) and the equity of this exchange; information dissemination between management and employees and among managers relates to information generated internally about the needs of employees, and their requirements, which is shared and communicated across departments; 3) responsiveness relates to the implementation of appropriate strategies and action plans, the form of required job designs, salaries, perks, share in profits, and non-monetary benefits (Lings and Greenley, 2001).

Research on internal market orientation is relatively recent (Gounaris, 2008) and research in this field still remains very conceptual, especially those studies undertaken 
between the 1980s and 1990s (Panigyrakis and Theodoridis, 2009). It is important to emphasise that the implementation of internal marketing involves the application of marketing inside the organisation and has been associated with specific organisational objectives. That is, its effectiveness should correspond to successful marketing initiatives (Gounaris, 2006) with internal and external consequences for the organisation (Lings and Greenley, 2005). However, from an internal perspective, it is noteworthy that managers' behaviour towards their subordinates influences their attitudes and behaviours (Ahmed and Rafiq, 2003) impacting, for instance, on job satisfaction (Lings and Greenley, 2005) and organisational commitment (Piercy and Morgan, 1990). From an external perspective, it may influence customer satisfaction and loyalty (Lings and Greenley, 2005; Kaur et al., 2009), service quality (George, 1990; Lings, 2000) and financial performance (Tanshuaj et al., 1988).

Recently there have been some studies that attach importance to the under-examined relationship between the internal marketing implementation and financial and non-financial performance in the commercial sectors (Panigyrakis and Theodoridis, 2009). The importance of this association is widely recognised. However, two aspects can be pointed out as under-explored areas: the consideration of the individual dimensions of the internal market orientation construct, and the analysis of this relationship in the public sector.

So taking the above into account, this study adopts a sub-component approach by considering the three aforementioned dimensions of internal market orientation and examines their impact on organisational performance. Although the use of aggregated approaches of market orientation is not completely original, in previous literature (Cheng and Krumwiede, 2010) the link between different internal market orientation dimensions and organisational performance is far from being fully explained. This is particularly relevant if we consider the public sector context.

One of the few studies that have addressed this issue was undertaken by Tortosa et al. (2009) who analysed the banking setting. These authors examined the influence of internal marketing on satisfaction of the front-line personnel, on one hand, and on the other, they analyse the related external aspects of the organisation, associated with perceived quality of service and organisational performance.

Based on the preceding discussion, it is assumed that internal market orientation dimensions could have an important impact on financial and non-financial indicators of public sector organisational performance. Therefore, the following hypotheses are proposed:

H4. Internal information generation (IG) has a direct, positive and significant impact on financial performance $(H 4 a)$ and on non-financial performance $(H 4 b)$.

H5. Internal information dissemination (ID) has a direct, positive and significant impact on financial performance ( $H 5 a)$ and on non-financial performance $(H 5 b)$.

H6. Internal responsiveness $(\mathrm{R})$ has a direct, positive and significant impact on financial performance $(H 6 a)$ and on non-financial performance $(H 6 b)$.

\section{Methodology}

Data collection procedure

The local public sector, specifically municipal authorities were selected due to their proximity to citizens and due to the vast changes that have been occurred in this specific
The impact of market orientation

291 
MIP

30,3

292 sector of public administration. The Portuguese local public sector, which is the focus of the present study, is comprised of 308 Municipalities. Relying on a convenience sample procedure, it was decided to select only those Municipalities of the North Region of Portugal due to its overall country representativeness and due to constraints associated with time and resources. Executive board members were chosen as the unit of analysis for this study (a total of 354 members). The reason for this choice is that they are in a better position to evaluate organisational dynamics as they participate actively in the achievement of organisational objectives. Focusing on the executive board members made it possible to access relevant information due to their prominent role in defining tactical and strategic activities. Of the 354 self-administered questionnaires mailed to executive board members, a total of 118 completed questionnaires were returned, yielding a usable response rate of 33 per cent. This response rate compares favourably with other studies on market orientation (Jaworski and Kohli, 1993).

Non-response bias was assessed by comparing early to late respondents (Armstrong and Overton, 1977). We define early respondents as the first 80 per cent to return questionnaires and late respondents as the last 20 per cent. Univariate tests of significance ( $t$-tests) were conducted and no significant difference was found between the two sets of respondents along the most important constructs. Thus, non-response bias did not appear to be a serious problem in the current study.

\section{Measurement scales}

In order to develop appropriate measures for this study, standard psychometric scale construction procedures were followed. Most scales used in this study have been sourced from literature in the field of public organisations and, in some cases, modified for the current context. Several procedures were developed to improve content validity, and in particular the questionnaire was pre-tested to ensure the appropriate meanings. The pre-test was used with academics and practitioners and helped to clarify ambiguous questions. Their comments and suggestions were taken into account in the final version of the questionnaire. All construct measures used in this study were rated on a five-point Likert scale.

External market orientation. The development of this measurement scale was based on Cervera et al. (2001) who adapted the original scale of Kohli et al. (1993) to the local public sector. Three dimensions have been considered, namely:

(1) external information generation;

(2) external information dissemination; and

(3) external information response.

Some changes were made to the items to suit the characteristics of the sampled organisations.

Internal market orientation. Following the approach developed by Lings and Greenley (2005) this scale included 16 items. In operationalizing this construct, Lings and Greenley (2005) modified the internal market orientation scale developed by Kohli and Jaworski (1990) for the transaction context between employees and employers.

Organisational performance. The existence of multiple, and sometimes conflicting objectives, makes performance assessment difficult for public sector managers. However, two sets were considered to measure this construct. The first set was financial based, including the Common Assessment Framework, particularly: degree of 
budgetary accomplishment, degree of attainment of financial objectives, growth in income, size of profit/surplus, efficient use of assets and funds and degree of activities performed to generate funding/income; The second set was non-financial based and included the following items: organisational labour climate, degree of employees' skills and competencies, and citizen satisfaction with services provided by the municipality.

Relying on subjective (rather than objective) measures appears to be justified since previous studies have found a strong correlation between subjective assessments and organisational performance (Dess and Robinson, 1984; Slater and Narver, 1994).

\section{Findings}

Sample profile and the measurement model results

From a total of 118 executive board members, the characteristics of the sample indicated that the majority of the respondents were male, age between 36 to 45 years old, with a high academic level. Of the 70 Municipalities represented in the sample the number of full-time employees ranged from 56 to 3,266. In terms of resident population of the Municipalities the number of inhabitants varied from 3,378 to 300,868 .

A series of tests were undertaken to ensure that the internal and external market orientation scales and organisational performance scale retained their psychometric properties when employed in a Portuguese setting. To purify the initial measures and to ensure the homogeneity of original scales, several item-to-item correlations were performed and items that showed a low item-to-total correlation or high cross-loadings were dropped from the analysis.

The structural equation modelling (SEM) was considered to be the most appropriate analytical methodology for testing the proposed model. Following Anderson and Gerbing's (1988) suggestions, the analysis was conducted in two steps. First, a measurement model was analysed through confirmatory factor analysis (CFA); second, the structural model was evaluated to assess the hypothesised relationships between constructs.

Initial data screening and preparation was accomplished using EQS 6.1 (Bentler, 2006). Mardia's coefficient was used to measure multivariate kurtosis and provided an indication that the data are relatively free from multivariate kurtosis. Additionally, all responses exhibited good univariate normality with all distributions indicating a skewness less than 1 and a kurtosis less than 2 in absolute value. These values are well within the robust thresholds for maximum-likelihood estimation. To address the common method variance bias, we applied Harman 1-factor test (Podsakoff and Organ, 1986) on all measurement variables of our research model. All variables were entered into a principal component analysis with varimax rotation. In case a single factor emerges from the analysis or one general factor accounts for the most covariance in the measure scores, common method variance may be present. The results of this analysis found no significant biases in the dataset so we assumed the nonexistence of this type of bias.

The psychometric properties of the scales were assessed through confirmatory factor analysis (CFA), using the maximum likelihood method (MML) (Fornell and Larcker, 1981). After performing the CFA for each proposed measurement scale to evaluate its unidimensionality, the item pools were purified by dropping those which revealed weak convergence, low standardised loadings and low $R^{2}$. During this process a number of items were discarded from the analysis. Information pertaining to the summary statistics of the measurement model (factor loadings and $t$-values; Cronbach's alphas, average

\section{The impact of market orientation}

293 
MIP

30,3

294 variance extracted and composite reliability of all the scales) are given in Appendix 1 . The reliability of most of the constructs met the recommended standard of 0.70 suggested by Nunnally (1978). The scales of external information dissemination produced Cronbach's alpha values of 0.65 which were slightly lower than 0.70 . Composite reliability represents the shared variance among a set of observed variables measuring an underlying construct (Fornell and Larcker, 1981). In general, a composite reliability of at least 0.6 is considered desirable (Bagozzi and Yi, 1988, p. 82). As shown in Table I, each construct met that criterion. Similarly, the AVE for all constructs can be considered satisfactory (above 0.50) (Bagozzi and Yi, 1988). Overall, most scale psychometric properties examination shows unidimensionality and conceptual consistency.

The standardised loadings and their associated $t$-values were also examined. Convergent validity is revealed by the large and significant standardised loadings $(t>$ $1.96 ; p<0.05)$. With regard to discriminant validity we tested whether all the construct inter-correlations were significantly different from 1 , and that the square root of AVE was greater than the variance shared between the latent construct and other latent constructs in the model (i.e. the square correlation between two constructs) (Barclay et al., 1995). All latent constructs satisfy this condition (Table I).

Only the information dissemination dimension of (external) market orientation showed some inconsistency. However, it was decided to maintain this dimension because of its theoretical relevance. Based on the above analysis, it was concluded that most constructs had adequate measurement properties. After examining the construct validity and the reliability of the measurement model, the next step was to assess whether the structural model supported the proposed theoretical model.

\section{Structural model results and discussion}

The parameter estimates and model fit statistics of the proposed structural model for external market orientation are presented in Table II. $H_{1}$ to $H_{3}$ examine the impact of external market orientation dimensions, such as information generation, dissemination and responsiveness on financial (a) and non-financial performance (b).

The results indicate that external information generation is positively and significantly related to financial performance (supporting $H_{1 a}$ ) and not related to non-financial performance (not supporting $H_{1 b}$ ). External information dissemination fails to be significantly related to financial performance but positively affects non-financial performance. Thus, $H_{2 b}$ is supported and $H_{2 a}$ is not supported. This finding is in line with the results of Dawes' (2000) study. In this research, Dawes (2000) uses "market information sharing" (defined as the dissemination of market-related information between departments) as a proxy of Kohli and Jaworski's "dissemination" market orientation component. The author also did not find any relationship between this dimension and financial performance (profitability).

Finally, external responsiveness is positively and significantly related to financial and non-financial performance (supporting $H_{3 a}$ and $H_{3 b}$ ). This is in line with Chao and Spillan (2010), who found that responsiveness was the only significant predictor of three market orientation components that impacts positively on both financial and non-financial performance.

The parameter estimates and model fit statistics of the proposed structural model for internal market orientation are presented in Table III. 


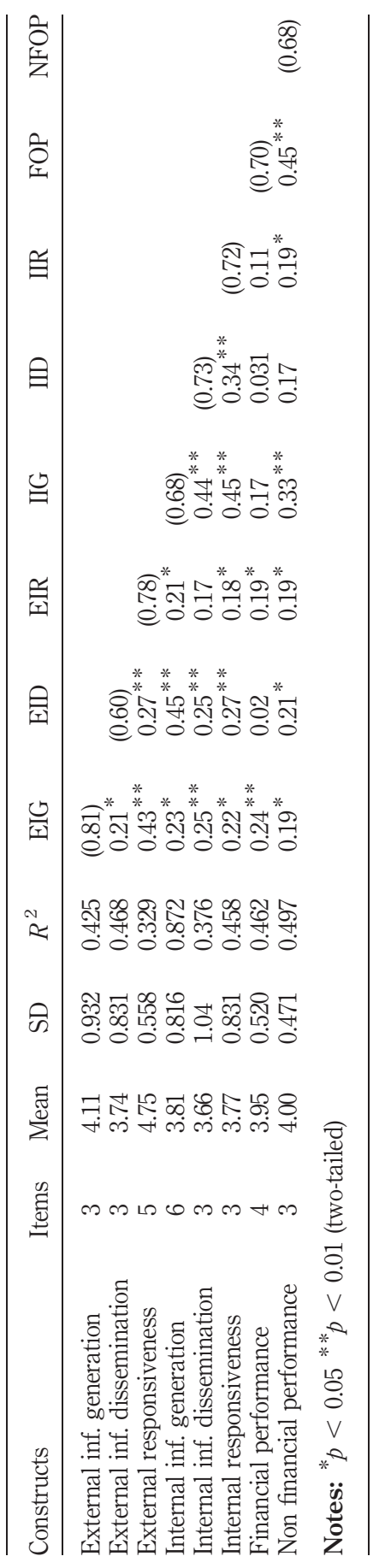

\section{The impact of market orientation}

295

Table I.

Descriptive statistics and the correlation matrix 
MIP

30,3

296

As results from Table III shows the relationships arisen from internal information generation have a positive impact on either financial or non-financial performance $(H 4$ to H6). Thus, $H_{4 a}$ and $H_{4 b}$ are accepted. However, the data from the present study did not support $H_{5 a}, \mathrm{H}_{5 \mathrm{~b}}, H_{6 a}$ and $H_{6 b}$. These results are partly in line with those obtained by Tortosa et al. (2009) who reached similar results for the informal generation of internal information (internal information generation), which was a key finding of their study.

Results from this study revealed that: First, a review of existing literature finds that much of the empirical work in the market orientation-performance area has used an aggregated approach (Furrer et al., 2003). However, some recent studies (Dawes, 2000; Noble et al., 2002; Sin et al., 2005; Zhou et al., 2007; Tsiotsou, 2010) have claimed that the behaviour of the different market orientation sub-components may produce different results. Findings from this study add significance to this argument by offering different results when dealing with the impact of different sub-dimensions of market oriented (internally and externally) behaviours with performance.

Second, with regard to external market orientation it seems that the two dimensions of information gathering and responsiveness appear to be important dimensions to predict financial performance, in particular the degree of budgetary accomplishment, degree of accomplishment of financial objectives, the degree of activities performed to generate funding/income and efficient use of assets funds.

Furthermore, the external information dissemination dimension associated with responsiveness also seems to have a positive impact on non-financial performance, particularly regarding to the degree of organisational labour climate, degree of

Table II.

Estimation of path coefficients for external market orientation and performance

\begin{tabular}{lccll}
\hline Paths in the theoretical model & $\begin{array}{c}\text { Standardised } \\
\text { coefficient }\end{array}$ & $t$-value & SE & Hypothesis support \\
\hline External IG $\rightarrow$ Financial performance & $0.271^{*}$ & 2.47 & $0.11 \mathrm{H}_{a}-$ Yes \\
External ID $\rightarrow$ Financial performance & 0.195 & 1.67 & $0.07 \mathrm{H}_{a}-$ No \\
External RI $\rightarrow$ Financial performance & $0.311^{* *}$ & 3.00 & $0.12 \mathrm{H} 3_{a}-$ Yes \\
External IG $\rightarrow$ Non-financial performance & 0.076 & 0.77 & $0.09 \mathrm{H}_{b}-\mathrm{No}$ \\
External ID $\rightarrow$ Non-financial performance & $0.480^{* *}$ & 3.77 & $0.07 \mathrm{H}_{b}-$ Yes \\
External RI $\rightarrow$ Non-financial performance & $0.281^{* *}$ & 2.80 & $0.11 \mathrm{H} 3_{b}-$ Yes
\end{tabular}

Notes: ${ }^{*} p<0.05 ; * * p<0.01$; Fit indices: Absolute fit: $\chi^{2}=193$; df $=122$, Prob. 0.0004; CFI = 0.94; $\mathrm{RMSEA}=0.071 ; \mathrm{NFI}=0.86 ; \mathrm{IFI}=0.94$

Table III.

Estimation of path coefficients for internal market orientation and performance

\begin{tabular}{lcrlll}
\hline Paths in the theoretical model & $\begin{array}{c}\text { Standardised } \\
\text { coefficient }\end{array}$ & $t$-value & SE & Hypothesis support \\
\hline Internal IG $\rightarrow$ Financial performance & $0.367^{*}$ & 2.34 & $0.11 H_{a}-$ Yes \\
Internal ID $\rightarrow$ Financial performance & 0.029 & -0.20 & 0.08 & $H_{a}-$ No \\
Internal RI $\rightarrow$ Financial performance & 0.110 & 0.72 & 0.11 & $H 6_{a}-$ No \\
Internal IG $\rightarrow$ Non-financial performance & $0.301^{*}$ & 2.02 & 0.11 & $H 4_{b}-$ Yes \\
Internal ID $\rightarrow$ Non-financial performance & 0.036 & -0.25 & 0.07 & $H 5_{b}-$ No \\
Internal RI $\rightarrow$ Non-financial performance & 0.253 & 1.69 & $0.11 \quad H b_{b}-$ No
\end{tabular}

Notes: ${ }^{*} p<0.05$; Fit indices: Absolute fit: $\chi^{2}=224 ; \mathrm{df}=140$, Prob. $0.0001 ; \quad \mathrm{CFI}=0.93$; $\mathrm{RMSEA}=0.072 ; \mathrm{NFI}=0.82 ; \mathrm{IFI}=0.93$ 
employee's skills and competencies and degree of citizens satisfaction. Broadly speaking, we may conclude that most external market orientation sub-dimensions have a significant impact on both financial and non-financial performance (four out of six) when compared to internal market orientation sub-dimensions (two out of six).

Third, with regard to internal market orientation it is interesting to note that the only dimension that impacts positively on both financial and non-financial performance is the internal information generation sub-dimension. This justifies the need for managers to regularly generate and disseminate information about what employees want from the municipality and their real feelings about their jobs. In order to achieve this, managers should carry out regular staff appraisals and should undertake a good deal of internal market research. This finding provides an important insight into the debate on internal marketing regarding the need to collect and analyse information relative to the internal market (Panigyrakis and Theodoridis, 2009).

By contrast, internal information dissemination and responsiveness did not impact on both financial and non-financial performance. A possible explanation for this relates to the fact that although public managers are mainly concerned with gathering information about current and future customer needs, they are reluctant to disseminate this information to their employees. Additionally, they are not sufficiently responsive to the needs of their employees, which may suggest that public managers still exercise bureaucratic, formalised control based on a limited set of explicit rules that define the course of action to be undertaken in different contexts. Specifically, they do not usually take corrective action to minimise dissatisfaction, they do not modify their conditions of employment and do not make changes when employees indicate that they are dissatisfied. Although not examined in this article, it can be assumed that job satisfaction and organisational commitment may have a positive impact on organisational performance (Petty et al., 1984). One possible recommendation is to analyse the strength of employees' feelings towards the organisation. In other words, the more satisfied and committed the employees are, the greater their willingness to engage in behaviours that are vital for the organisation's success. For instance, Petty et al. (1984) found that job satisfaction is positively correlated to organisational performance.

In summary, in line with previous studies (Jaworski and Kohli, 1993; Narver and Slater, 1990), all three external market orientation dimensions are important and "provide a holistic view of firms' ability to collect and use market information effectively" (Grinstein, 2008, p. 167). With regard to the internal market orientation organisational performance link it seems that activities that generate internal information can be successfully used to identify superior value for the internal clients. However, information sharing and communication across functional units and responsiveness to that internal information does not positively affect the performance indicators. It could be said that these findings emphasise the difficulties local public organisations face in effectively implementing such internal orientation.

\section{Conclusions and implications}

This study contributes to a better understanding of implementing an internal and external market orientation in public organisations with the ultimate objective of creating enhanced value to both publics: employees and customers/citizens. This paper began by looking at whether the success of public sector initiatives can only be accomplished through a clear view of the needs of internal and external publics:

\section{The impact of market orientation}

297 
MIP

30,3

298

employees and citizens (Jones et al., 2007). Throughout this study, attention has been concentrated on the influence of different internal and external market orientation components on financial and non-financial performance indicators. A conceptual model was presented and the case of the Portuguese local public sector organisations was analysed.

Results of this study have particular relevance for both marketing theory and practice. From the standpoint of theory, as previously mentioned, this study addressed an important topic that was neglected in relevant literature, particularly the analysis of the relationship between different sub-dimensions of internal and external market orientations to both financial and non-financial performance. This is in line with the call for research by several authors in this particular field (Han et al., 1998; Noble et al., 2002; Grinstein, 2008; Tsiotsou, 2010).

The relative roles of the sub-dimensions of internal and external market orientation and their impact on organisational performance provide a fertile arena for research. It can be argued that an understanding of the aforementioned relationships is an important contribution to improve knowledge in one of the most crucial concepts of marketing - the concept of market orientation. Similarly, concerning the internal market orientation research stream, this is one of the very few studies that have been specifically focused on a sub-dimension approach and its impact on organisational performance. Thus, this study contributes to the body of internal marketing research by providing empirical findings relative to an under-researched relationship between internal market orientation and performance (Panigyrakis and Theodoridis, 2009) and by investigating the influence of each internal market orientation dimension on organisational performance (Tortosa et al., 2009).

Additionally, to the best of our knowledge this is one of the few studies that reports results from the analysis of internal and external market orientation sub-dimensions with financial and non-financial performance in local public sector organisations. It is important to understand how previous relationships are perceived within different organisational and cultural contexts. It should be noted that most of previous studies devoted to market orientation have primarily been focused on for-profit sector.

This study includes an important sector that has been undergoing profound transformation because of the worldwide phenomenon of "redesigning public sector administration on the basis of NPM principles (Rod and Ashill, 2010, p. 601). The relevance of this study was justified by the fact that the public sector has been undergoing profound changes in order to bring about a new organisational model, which is closer to management-oriented practices. In line with other areas of the public sector, local government increasingly faces a changing external and internal environment that challenges its traditional bureaucratic "modus operandi". Recent transformations and modernisation efforts, especially those concerned with the introduction of business-like management practices and the developments in information communication technologies, have highlighted the importance of offering citizen-centric services that deliver real measurable public value (McDonald et al., 2006). To accomplish this aim, public managers can learn a great deal from market-oriented approaches which have an important role in defining those priorities, that fulfil customer and citizen needs.

Apart from these theoretical contributions, this study has some important implications for local public sector managers and policy makers. Nowadays, due to 
turbulent, complex and constantly changing environments, organisations at all levels (and especially those in the local public sector) are increasingly pressured to re-evaluate their activities, based on more stringent criteria in terms of transparency and accountability. As mentioned in the introduction, this has driven local public organisations to be more efficient by incorporating internal and external marketing approaches, in which the needs of both its publics: internal (employees) and external (customers/citizens) are at the centre of activity (Drummond et al., 2000) of the transformational government process.

The findings reported in this study can provide public sector managers with specific knowledge that would enable them to respond to market turbulence and to meet marketplace demands. Local public executives need to recognise the importance of allocating organisational resources to ensure the efficient collection and dissemination of and responsiveness to intelligence, which can be addressed internally and externally. By incorporating these activities into their organisational structures, local public organisations create the necessary conditions to be more successful and, as a result, to enhance their performance. This is consistent with Osborne (2010) who observed that successful public service provision implies both governing and responding to the service expectations of consumers and training and motivating the organisation to interact positively with the consumer.

Those responsible for local public sector organisations should take the necessary actions to define which priorities should be devoted to different public types (internal and external). Otherwise, they will not succeed. Also, knowing the influence of which external and internal market orientation sub-dimensions better impact on organisational performance provides knowledge about how local public managers should provide better value to employees and customers. This study also found that, from an internal perspective, local public organisation still rely on bureaucratic mechanisms of control based on an extensive set of rules, regulations and procedures that clearly limit local managers' authority. This conclusion can be drawn from the fact that internal information dissemination and market responsiveness are critical factors that did not enhance organisational performance.

\section{Limitations and future research directions}

This study is inevitably subject to a number of limitations, which should be borne in mind while interpreting its results. The study also opens several fruitful avenues for future research.

Since this work is entirely based on evidence from local public organisations of a specific Portuguese region, results should be interpreted with some caution. Although this approach allows for a deeper understanding of the actors under investigation (due to the homogeneity of the respondents), no generalisations to other regions (or countries) can be made. Future studies should examine the same relationships with a wider sample or even including organisations from different sectors.

Moreover, the single-informant design represents a limitation. This study has considered the Municipality executives as the main unit of analysis. Further studies should also take into account other stakeholders (such as customers and employees). In addition, this study used cross-sectional data to test the research model and hypotheses, but internal marketing, market orientation, and organisational performance are dynamic constructs, involving elements of time, which may be

\section{The impact of market orientation}

299 
MIP

30,3

300 better examined over an extended period. Thus, future research through longitudinal design is desirable to accomplish this objective.

A further limitation relates to the measurement of internal market orientation and market orientation. Alternative conceptualisations of both constructs could also be examined in future research. The measure used for organisational performance focused on certain aspects of performance, which overlook other possible indicators. Consequently, future research could broaden the measures of this study.

Finally, the constraints on the sample size have to be taken into account. Although a number of authors (Hair et al., 2006) have argued that the minimum sample size to ensure appropriate use of ML estimation, such as in the case of this study, ranges between 100 and 150, the interpretation of these findings and their generalisation should be undertaken with caution.

Other research directions could be pointed out. For example, future research could adopt a more comprehensive approach by examining the possible causal order of the dimensions of internal and external market orientation, and their potential interaction effects. Studying the relationships between the dimensions of internal and external market orientation and the success of public sector organisations could provide an interesting topic for future research. Moreover, in this research internal and external market orientations are viewed independently but future research could usefully investigate the inter-relationships between the two orientations, as their joint effect could shed new light on the dynamics of two traditionally separated areas of study. What is more, there are future research opportunities for the application of these models to other non-profit sectors or even for making a comparative analysis of public and private sectors.

\section{References}

Ahmed, P.K., Rafiq, M. and Saad, N.M. (2003), "Internal marketing and the mediating role of organisational competencies", European Journal of Marketing, Vol. 37 No. 9, pp. 1221-41.

Anderson, J.C. and Gerbing, D.W. (1988), "Structural equation modeling in practice: a review and recommended two-step approach”, Psychological Bulletin, Vol. 103 No. 3, pp. 411-23.

Andreasen, A. and Kotler, P. (2003), Strategic Marketing for Non-profit Organizations, Prentice Hall, Englewood Cliffs, NJ.

Andrews, R., Boyne, G. and Walker, R. (2011), "The impact of management on administrative and survey measures of organizational performance", Public Management Review, Vol. 13 No. 2, pp. 227-55.

Appiah-Adu, K. and Ranchhod, A. (1998), "Market orientation and performance in the biotechnology industry: an exploratory empirical analysis", Technology Analysis \& Strategic Management, Vol. 10 No. 2, pp. 197-210.

Araújo, J. (2001), "Improving public service delivery: the crossroads between NPM and traditional bureaucracy”, Public Administration, Vol. 79 No. 4, pp. 915-32.

Armstrong, J.S. and Overton, T.S. (1977), "Estimating nonresponse bias in mail surveys", Journal of Marketing Research, Vol. 14, pp. 396-402.

Bagozzi, R. and Yi, Y. (1988), "On the evaluation of structural equation models", Journal of the Academy of Marketing Science, Vol. 16 No. 1, pp. 74-94.

Balakrishnan, S. (1996), "Benefits of customer and competitive orientations in industrial markets”, Industrial Marketing Management, Vol. 25 No. 4, pp. 257-69. 
Ballantyne, D. (2000), "The strengths and weaknesses of internal marketing”, in Varey, R.J. and Lewis, B.R. (Eds), Internal Marketing - Directions for Management, Taylor \& Francis Group, London, pp. 43-60.

Barclay, D., Thompson, R. and Higgins, C. (1995), "The partial least squares (PLS) approach to causal modelling: personal computer adoption and use as an illustration", Technology Studies, Vol. 2 No. 2, pp. 285-309.

Bentler, P. (2006), EQS Structural Equations Program Manual, Multivariate Software, Encino, CA.

Berry, L. (1981), “The employee as customer”, Journal of Retail Banking, Vol. 3 No. 1, pp. 25-8.

Brignall, T.J. and Ballantine, J. (1996), "Performance measurement in service businesses revisited”, International Journal of Service Industry Management, Vol. 7 No. 1, pp. 6-31.

Cano, C.R., Carrillat, F.A. and Jaramillo, F. (2004), "A meta-analysis of the relationship between market orientation and business performance: evidence from five continents", International Journal of Research in Marketing, Vol. 21, pp. 179-200.

Caruana, A., Ramaseshan, B. and Ewing, M.T. (1998), "The market-orientation-performance link: some evidence from the public sector and universities", Journal of Nonprofit \& Public Sector Marketing, Vol. 6 No. 1, pp. 63-82.

Carver, C.S. (1989), "How should multifaceted personality constructs be tested? Issues illustrated by self-monitoring, attributional style, and hardiness", Journal of Personality and Social Psychology, Vol. 56 No. 4, pp. 577-85.

Cervera, A. (1998), "La orientación al mercado: un modelo en el âmbito de los gobiernos locales", doctoral dissertation, Faculdade de Ciências Económicas e Empresariais, Valência.

Cervera, A., Mollá, A. and Sánchez, M. (2001), "Antecedents and consequences of market orientation in public organisations", European Journal of Marketing, Vol. 35 Nos 11-12, pp. 1259-86.

Chao, M.C.-H. and Spillan, J.E. (2010), "The journey from market orientation to firm performance - a comparative study of US and Taiwanese SMEs", Management Research Review, Vol. 33 No. 5, pp. 472-83.

Cheng, C.C. and Krumwiede, D. (2010), "The effects of market orientation and service innovation on service industry performance: an empirical study", Operational Management Research, Vol. 3, pp. 161-71.

Dawes, J. (2000), "Market orientation and company profitability: further evidence incorporating longitudinal data", Australian Journal of Management, Vol. 25 No. 2, pp. 173-99.

Day, G.S. and Wensley, R. (1988), "Assessing advantage: a framework for diagnosing competitive superiority", Journal of Marketing, Vol. 52 No. 2, pp. 1-20.

Denhardt, R. and Denhardt, J. (2000), "The new public service: serving rather than steering", Public Administration Review, Vol. 60 No. 6, pp. 549-59.

Dess, G.G. and Robinson, R.B. (1984), "Measuring organizational performance in the absence of objective measures: the case of privately-held firm and conglomerate business units", Strategic Management Journal, Vol. 5 No. 3, pp. 265-73.

Drummond, G., Ensor, J., Laing, A. and Richardson, N. (2000), "Market orientation applied to police service strategies", The International Journal of Public Sector Management, Vol. 13 No. 7, pp. 571-87.

Fornell, C. and Larcker, D.F. (1981), "Evaluating structural equation models with unobservable variables and measurement error", Journal of Marketing Research, Vol. 18, February, pp. 39-50.

\section{The impact of market orientation}

301 
MIP

30,3

302

Furrer, O., Lantz, C. and Peninjaquet, A. (2003), “The impact of employees' individual values on their attitudes toward market orientation", Proceedings of 32nd EMAC Conference, Glasgow, Scotland, 2003.

George, W.R. (1990), "Internal marketing and organisational behaviour: a partnership in developing customer-conscious employees at every level”, Journal of Business Research, Vol. 20 No. 1, pp. 63-70.

Gounaris, S. (2008), "Antecedents of internal marketing practice: some preliminary empirical evidence”, International Journal of Service Industry Management, Vol. 19 No. 3, pp. 400-34.

Gounaris, S.P. (2006), "Internal-market orientation and its measurement", Journal of Business Research, Vol. 59 No. 4, pp. 432-48.

Greene, W.E., Wall, G.D. and Schrest, L.J. (1994), "Internal marketing: the key to external marketing success", The Journal of Services Marketing, Vol. 8 No. 4, pp. 5-13.

Greenley, G.E. (1995), "Market orientation and company performance: empirical evidence from UK companies", British Journal of Management, Vol. 6 No. 1, pp. 1-13.

Grinstein, A. (2008), "The effect of market orientation and its components on innovation consequences: a meta-analysis", Journal of the Academy of Marketing Science, Vol. 36, pp. 166-73.

Grönroos, C. (1981), "Internal marketing - an integral part of marketing theory", in Donnelly, J.H. and George, W.R. (Eds), Marketing of Services, American Marketing Association, Chicago, IL, pp. 236-8.

Gummesson, E. (2000), "Internal marketing in the light of relationship marketing and network organisations", in Varey, R.J. and Lewis, B.R. (Eds), Internal Marketing - Directions for Management, Taylor \& Francis Group, London, pp. 27-41.

Hair, J., Black, W., Babin, B., Anderson, R. and Tatham, R. (2006), Multivariate Data Analysis, 6th ed., Pearson Prentice Hall International, Upper Saddle River, NJ.

Han, J.H., Kim, N. and Srivastava, R. (1998), "Market orientation and organizational performance: is innovation a missing link?", Journal of Marketing, Vol. 62, pp. 30-45.

Harris, L.C. (2003), "Measuring market orientation: exploring a market oriented approach", Journal of Market-Focused Management, Vol. 5, pp. 239-70.

Hood, C. (1995), "The 'new public management' in the 1980s: variations on a theme", Accounting, Organizations and Society, Vol. 20 Nos 2/3, pp. 93-109.

Jaworski, B.J. and Kohli, A.K. (1993), "Market orientation: antecedents and consequences", Journal of Marketing, Vol. 57, July, pp. 53-70.

Jaworski, B.J. and Kohli, A.K. (1996), "Market orientation: review, refinement and roadmap", Journal of Market-Focused Management, Vol. 1 No. 2, pp. 119-35.

Jones, S., Hackney, R. and Irani, Z. (2007), "Towards e-government transformation: conceptualising citizen engagement: a research note", Transforming Government: People, Process and Policy, Vol. 1 No. 2, pp. 145-52.

Kara, A., Spillan, J.E. and DeShields, O.W. (2004), “An empirical investigation of the link between market orientation and business performance in non-profit service providers", Journal of Marketing Theory and Practice, Vol. 22 No. 2, pp. 59-72.

Kaur, G., Sharma, R.D. and Seli, N. (2009), "Internal market orientation in Indian banking: an empirical analysis”, Managing Service Quality, Vol. 19 No. 5, pp. 595-627.

Keat, R. and Abercrombie, N. (Eds.) (1991), Enterprise Culture, Routledge, London. 
Kirca, A., Jayachandran, S. and Bearden, W.O. (2005), "Market orientation: a meta-analytic review and assessment of its antecedents and impact on performance", Journal of Marketing, Vol. 69, April, pp. 24-41.

Kohli, A.K. and Jaworski, B.J. (1990), "Market orientation: the construct, research propositions, and management implications", Journal of Marketing, Vol. 54, April, pp. 1-18.

Kohli, A.K., Jaworski, B.J. and Kumar, A. (1993), "MARKOR: a measure of market orientation", Journal of Marketing Research, Vol. 30, November, pp. 467-77.

Li, T. and Calantone, R.J. (1998), "The impact of market knowledge competence on new product advantage: conceptualization and empirical examination”, Journal of Marketing, Vol. 62, October, pp. 13-29.

Lings, I.N. (1999), "Balancing internal and external market orientations", Journal of Marketing Management, Vol. 15, pp. 239-63.

Lings, I.N. (2000), "The impact of internal market orientation on external market orientation and business performance: an empirical study of the UK retail market", Proceedings of ANZMAC 2000 Conference, Visionary Marketing for the 21st Century: Facing the Challenge, pp. 697-702.

Lings, I.N. (2004), "Internal market orientation: construct and consequences", Journal of Business Research, Vol. 57, pp. 405-13.

Lings, I.N. and Greenley, G.E. (2005), "Measuring internal market orientation”, Journal of Service Research, Vol. 7 No. 3, pp. 290-305.

Lings, I.N. (2005), "The impact of internal and external market orientation on firms performance", pp. 42-50, available at: www.anzmac2005.conf.uwa.edu.au/ (accessed 16 April, 2008).

Lings, N.I. and Greenley, G.E. (2001), "The development and validation of a measure of internal market orientation”, Aston Business School Research Papers, Aston Business School, Birmingham, pp. 1-32, available at: www.abs.aston.ac.uk/ (accessed 25 June, 2008).

Lukas, B.A. and Ferrell, O.C. (2000), "The effect of market orientation on product innovation", Journal of the Academy of Marketing Science, Vol. 28 No. 2, pp. 239-47.

Macedo, I. and Pinho, J.C. (2006), "The relationship between resource dependence and market orientation”, European Journal of Marketing, Vol. 40 Nos 5-6, pp. 533-53.

McDonald, N., Blakemore, M. and Kelleher, J. (2007), “Think Paper 9: Aarhus Seminar Discussion Paper: towards a handbook for citizen-centricity, organizational change for citizen-centric e-government", e-Government Unit, DG Information Society and Media, European Commission, available at: www.ccegov.eu/int/egovernment_research (accessed 20 February, 2008).

Narver, J.C. and Slater, S.F. (1990), "The effect of a market orientation on business profitability", Journal of Marketing, Vol. 54 No. 4, pp. 20-35.

Noble, C.H., Sinha, R.K. and Kumar, A. (2002), "Market orientation and alternative strategic orientations: a longitudinal assessment of performance implications", Journal of Marketing, Vol. 6, October, pp. 25-39.

Nunnally, J.C. (1978), Psychometric Theory, McGraw-Hill, New York, NY.

Osborne, S. (2010), "Delivering public services: time for a new theory?", Public Management Review, Vol. 12 No. 1, pp. 1-10.

Panigyrakis, G.G. and Theodoridis, P.K. (2009), "Internal marketing impact on business performance in a retail contex", International Journal of Retail \& Distribution Management, Vol. 37 No. 7, pp. 600-28.

\section{The impact of market orientation}

303 
MIP

30,3

304
Papasolomou, I. (2006), "Can internal marketing be implemented within bureaucratic organisations", International Journal of Bank Marketing, Vol. 24 No. 3, pp. 194-212.

Petty, M., McGee, G. and Cavender, J. (1984), "A meta-analysis of the relationship between individual job satisfaction and individual performance", Academy of Management Review, Vol. 9 No. 4, pp. 712-21.

Piercy, N.F. and Morgan, N.A. (1990), "Internal marketing: making marketing happen", Marketing Intelligence \& Planning, Vol. 8 No. 1, pp. 4-6.

Piercy, N.F., Harris, L.C. and Lane, N. (2002), "Market orientation and retail operatives' expectations", Journal of Business Research, Vol. 55, pp. 261-73.

Pinho, J., Macedo, I. and Monteiro, A. (2007), "The impact of online SERVQUAL dimensions on certified accountant satisfaction”, EuroMed Journal of Business, Vol. 2 No. 2, pp. 154-72.

Podsakoff, P.M. and Organ, D.W. (1986), "Self-reports in organizational research: problems and prospects", Journal of Management, Vol. 12 No. 4, pp. 531-44.

Rafiq, M. and Ahmed, P.K. (2000), "Advances in the internal marketing concept: definition, synthesis and extension”, The Journal of Services Marketing, Vol. 14 No. 6, pp. 449-62.

Rod, M. and Ashill, N.J. (2010), "The effect of customer orientation on frontline employees' job outcomes in a new public management context”, Marketing Intelligence \& Planning, Vol. 28 No. 5, pp. 600-24.

Rodrigues, A.P. and Pinho, J.C. (2010), "Market orientation, job satisfaction, commitment and organisational performance: the specific case of local public sector", Transforming Government: People, Process and Policy, Vol. 4 No. 2, pp. 172-92.

Sin, L., Tse, A., Yau, O., Chow, R. and Lee, J. (2005), "Market orientation, relationship marketing orientation, and business performance: the moderating effects of economic ideology and industry type", Journal of International Marketing, Vol. 13 No. 1, pp. 36-57.

Slater, S.F. and Narver, J.C. (1994), "Does competitive environment moderate the market orientation performance relationship?", Journal of Marketing, Vol. 58 No. 2, pp. 46-55.

Tansuhaj, P., Randall, D. and McCullough, J. (1988), "A services marketing management model: integrating internal and external marketing functions", Journal of Services Marketing, Vol. 2 No. 1, pp. 31-8.

Tortosa, V., Moliner, M.A. and Sánchez, J. (2009), "Internal market orientation and its influence on organisational performance", European Journal of Marketing, Vol. 43 Nos 11/12, pp. 1435-56.

Tsiotsou, R.H. (2010), "Delineating the effect of market orientation on services performance: a component-wise approach”, The Service Industries Journal, Vol. 30 No. 3, pp. 375-403.

Varey, R.J. and Lewis, B.R. (1999), "A broadened conception of internal marketing”, European Journal of Marketing, Vol. 33 Nos 9/10, pp. 926-44.

Venkatraman, N. and Ramanujam, V. (1986), "Measurement of business performance in strategy research: a comparison of approaches", Academy of Management Review, Vol. 11, pp. 801-14.

Voss, G.B. and Voss, Z.G. (2000), "Strategic orientation and firm performance in an artistic environment", Journal of Marketing, Vol. 64, January, pp. 67-83.

Zhou, K.Z., Brown, J.R., Dev, C. and Agarwal, S. (2007), "The effects of customer and competitor orientations on performance in global markets: a contingency analysis", Journal of International Business Studies, Vol. 38, pp. 303-19. 
Appendix 1

Items for each construct
Internal information generation/formal face-to-face/formal
written
We try to find out what employees want from this
municipality
We try to find out our employees' real feelings about their
jobs
We regularly talk to our staff to find out about their work
We do a lot of internal market research
We have regular staff appraisals in which we discuss what
employees want
We often talk with our survey people to identify influences
on our employees' behaviour
Internal information dissemination
We regularly report back to our staff about issues that affect
their working environment
We regularly meet with all our staff to report about issues
relating to the whole municipality
We have regular staff meetings with employees of all levels
attending

Factor loadings
Coef.

Alpha $\quad \rho_{\mathrm{c}}^{\mathrm{a}} \quad \rho_{\mathrm{ve}}^{\mathrm{b}}$
The impact of market orientation
305
0.80

0.70

0.68

10.0

7.58

$0.61 \quad 6.70$

$0.56 \quad 6.09$

$0.54 \quad 5.10$

Internal responsiveness

When we find that employees would like us to modify their conditions of employment, the department make concerted efforts to do so

When we find out that employees are unhappy with our supervision or management, we take corrective action

We make changes to what we do when employee feedback indicates that they are dissatisfied with the status quo External information generation

This municipality is slow to detect changes about citizens' needs $(\mathrm{R})$

This municipality is slow to detect fundamental shifts in the public sector environment $(\mathrm{R})$

This municipality does not know the needs of those groups whose voice is not heard (ex: the illiterate, poor citizens) (R)

\section{External information dissemination}

In this municipality citizen information is communicated to all departments

The activities of the different departments in this municipality are well coordinated Employees in front-line activities have efficient communication systems at their disposal to report any problem that may arise

External responsiveness

In this municipality we do not use clear and simple language to communicate to citizens $(\mathrm{R})$
0.85

0.75

0.59

5.90

$\begin{array}{lll}0.77 & 0.77 \quad 0.53\end{array}$

7.40

$-$

5.90

$0.74 \quad 6.74$

$0.73-$

$0.73 \quad 6.72$

$\begin{array}{lll}0.83 & 0.85 & 0.67\end{array}$

$0.97 \quad 5.95$

$0.92 \quad 6.02$

$0.50 \quad-$

$\begin{array}{lllll}0.67 & - & 0.65 & 0.63 & 0.37\end{array}$

$0.62 \quad 4.12$

$0.52 \quad 3.809$

$\begin{array}{lll}0.87 & 0.88 & 0.61\end{array}$

$0.93 \quad 10.42$ $\begin{array}{lll}0.83 & 0.83 & 0.47\end{array}$ -
Table AI. Summary of statistics of the measurement model (CFA) 


\section{MIP 30,3}

306

Table AI.

\begin{tabular}{|c|c|c|c|c|c|}
\hline Items for each construct & $\begin{array}{c}\text { Factor } \\
\text { loadings }\end{array}$ & $t$-value & $\begin{array}{l}\text { Coef. } \\
\text { Alpha }\end{array}$ & $\rho_{\mathrm{c}}^{\mathrm{a}}$ & $\rho_{\mathrm{ve}}^{\mathrm{b}}$ \\
\hline $\begin{array}{l}\text { In this municipality we do not give information to citizens } \\
\text { about how to access and utilize services (R) }\end{array}$ & 0.89 & 9.88 & & & \\
\hline $\begin{array}{l}\text { In this municipality we do not give information to citizens } \\
\text { about their rights (R) }\end{array}$ & 0.79 & - & & & \\
\hline In this municipality contact with citizens/users is not easily & & & & & \\
\hline provided when it is effectively required $(\mathrm{R})$ & 0.71 & 8.51 & & & \\
\hline In this municipality citizen complaints fall on deaf ears (R) & 0.54 & 6.27 & & & \\
\hline Financial organisational performance & & & 0.82 & 0.80 & 0.50 \\
\hline Degree of financial objectives accomplishment & 0.80 & 7.42 & & & \\
\hline Degree of budgetary accomplishment & 0.76 & - & & & \\
\hline Measures related with the efficient use of assets funds & 0.67 & 6.89 & & & \\
\hline Degree of activities performed to generate funding/income & 0.60 & 5.93 & & & \\
\hline Non-financial organisational performance & & & 0.74 & 0.73 & 0.47 \\
\hline Degree of employee's skills and competencies & 0.72 & 4.26 & & & \\
\hline Degree of organisational labour climate & 0.68 & 4.20 & & & \\
\hline Degree of citizens satisfaction & 0.68 & 6.89 & & & \\
\hline
\end{tabular}

\section{About the authors}

Ana Paula Rodrigues (PhD, Universidade de Trás-os-Montes e Alto Douro) is an Assistant Professor of Marketing at University of Trás-os-Montes and Alto Douro, Vila Real, Portugal. She has been actively involved in a number of international projects, published in a number of international conference proceedings. Ana Paula Rodrigues is the corresponding author and can be contacted at: anarodri@utad.pt

José Carlos Pinho (PhD, Warwick University) is an Associate Professor of Marketing at School of Economics and Management, University of Minho, Campus de Gualtar, Braga, Portugal. His research in the field of marketing has been published in a vast number of international journals. He has been actively involved in a number of international projects, published in a number of international conference proceedings, served as reviewer for a number of international conferences and journals and has served as chair, track chair and co-chair for international conferences. Currently, he is the Director of the iMARKE (marketing and strategy research centre) and also acts as Course Director of the Marketing graduate course at Minho University.

To purchase reprints of this article please e-mail: reprints@emeraldinsight.com Or visit our web site for further details: www.emeraldinsight.com/reprints 